\title{
"Organic food is fertilised at night": Why people (do not) buy environmentally friendly products
}

Jan Činčera, Jan Stejskal, Martin Mach, Miroslav Lupač

Envigogika 9 (1) - Reviewed Papers/ Recenzované články

Published/Publikováno 30. 5. 2014

DOI: $\underline{10.14712 / 18023061.416}$

\begin{abstract}
The goal of this paper is to analyze barriers that discourage consumers from buying environmentally friendly products, and consequently suggest principles for effective consumer-oriented programmes of environmental education. It is based on a qualitative analysis of six focus groups $(\mathrm{N}=39)$ that were carried out with respondents from different consumer groups (mothers on maternity leave, pensioners, administrators, businessmen, university students, and environmental consultants). The research suggested that a lack of trust in the concept of sustainable consumption and consumers' personal history play important roles in consumer decision-making. In the final part, the article discusses the implications of these findings for environmental education.
\end{abstract}

\section{Key words:}

sustainable consumption; motivation; attitudes; barriers; Czech Republic; environmental education

\section{„Bio se hnojí v noci": proč lidé (ne)kupují environmentálně šetrné produkty}

\begin{abstract}
Abstrakt
Článek zkoumá důvody, které spotřebitele odrazují od nakupování výrobků šetrnějších k životnímu prostředí. Vychází z kvalitativní analýzy šesti ohniskových skupin $(\mathrm{N}=39)$, které byly provedeny se zástupci různých skupin spotřebitelů (matky na mateřské dovolené, senioři, úředníci, podnikatelé, studenti vysoké škole a ekoporadci). Výsledky ukazují na podobné motivy, které se objevily ve všech skupinách. Výzkum naznačil, že důležitou roli ve spotřebitelském rozhodování hraje nedostatek důvěry v koncept udržitelné spotřeby a osobní spotřebitelská historie. Respondenti předpokládají, že za cenu větší časové a finanční investice dostanou často dražší a méně funkční výrobky, o jejichž environmentální příznivosti navíc často pochybují. Protože současně nezpochybňují důležitost odpovědného environmentálního chování, je pro ně východiskem tzv. "přijatelně udržitelné spotřebitelské chování", podle kterého zohledňují environmentální aspekty v té oblasti spotřebitelského chování, která je pro ně snadno dostupná, zatímco je ignorují $v$ jiných.
\end{abstract}




\section{Klíčová slova}

udržitelná spotřeba, postoje, bariéry, Česká republika 


\section{Introduction}

Responsible consumption is one of the goals of environmental education. Hungerford and Peyton (based on Marcinkowski, 2005) defined consumerism as one of the key areas of environmentally friendly behaviour. Luchs and Mooradian (2012) defined sustainable consumer behaviour as behaviour motivated or influenced by social or environmental considerations. Therefore, consumers behaving in a sustainable way consider the impacts of a product on the community at its place of origin, the consumption of energy during its use, and its impact on environmental pollution upon disposal, for example. The UNEP (2013) defines sustainable consumption as "the use of services and related products which respond to basic needs and bring a better quality of life while minimizing the use of natural resources and toxic materials as well as the emissions of waste and pollutants over the life cycle of the service or product so as not to jeopardize the needs of further generations".

The topic of sustainable consumption is found in numerous environmental education programmes offered to various target groups. The best known examples in the Czech Republic include the programmes offered by NaZemi (Malírová, 2008; Malírová et al., 2008; Malířová et al., 2011; NaZemi, undated), providing information about the global impacts of consumerist behaviour and the Fair Trade brand, methodological handbooks for teachers containing ideas on organic food (Rykovská, 2006; Laštůvka, Kellnerová, and Křivánková, 2008), and activities and teaching classes on various areas of sustainable consumption (Anon, 2005; Martín, Ródenas, Serrano, and Fernández, undated; Šimonová, Činčera, Jančaříková, and Volfová, 2013). Their effect on the attitudes and behaviour of target groups, however, has only been examined peripherally (Činčera, 2013).

A chief prerequisite for the development of effective environmental education programmes that would motivate the public towards sustainable consumption is to understand the reasons why some consumers buy eco-friendly products while others do not. The objective of the present study was to try to analyse these reasons and, based on the presented findings and relevant literature, to propose how programmes promoting sustainable consumption ought to be oriented.

We assume that the present study will help start a debate on consumer-oriented environmental education programmes and further improve their quality.

\section{Theoretical framework}

Consumers' willingness to give preference to more environmentally and socially friendly products has been the subject of numerous research projects in various countries (Chan, 1999; Lockie, Lyons, Lawrence, and Mummery, 2002; Lea and Worsley, 2005; Noor, Muhammad, Kassim, Jamil, Mat, Mat, and Saleh, 2012; Angelovska, Sotiroska, and Angelovska, 2012; Szerenyi, Agnes, and Anna, 2011), including the Czech Republic (CVVM, 2013; Hadler and Wohlkönig, 2012; Ščasný, Urban, and Zvěřinová, 2013). Similarities and differences can be found across regions both in regard to the degree of willingness to purchase 'greener' products and development trends.

Laroche, Tomiuk and Barbaro-Forleo (2002) examined the influence of culture on environmental knowledge, attitudes and the behaviour of Canadian consumers. In their opinion, francophone consumers are more environmentally conscious, but anglophones show more willingness to pay for environmentally friendlier products. Based on an empirical survey comparing respondents from five countries and two different cultural backgrounds, Soyez (2012) says that while eco-centric values predominate in the Western 
cultural sphere, anthropocentric ones prevail in Russia. In her view, this influences consumer behaviour in both cultural regions.

In Central Europe, there is still a noticeable difference between countries that belonged to the former socialist bloc and the West, but the trend is one of a slow equalisation. While according to Hadler and Wohlkönig (2012), individual environmental behaviour, i.e., behaviour involving activities such as the purchasing of environmentally friendly products or reducing car use, has been more or less stagnating in Germany and Austria over the last ten years, it has been increasing in the Czech Republic, although it still remains below the levels of the two other countries. According to a CVVM (2013) survey, approximately $28 \%$ of Czech respondents always or often buy environmentally friendly products and $13 \%$ buy organic food as well. More than two-thirds of the population are interested in information on how to be more considerate to the environment.

The explanation of the causes why some consumers buy friendly products while others do not can be examined from several different perspectives. The first one focuses on demographic factors. Noor (2012) says that environmentally friendly products are bought more often by younger respondents, women, and richer respondents. According to Hadler and Wohlkönig (2012), key factors are age, gender and education, while older people, the better educated and women choose individual environmental behaviour more often than younger people, better educated and men. The model of the older, richer woman as a responsible consumer is also cited by Angelovska et al. (2012). According to CVVM (2013), more interest in environmentally responsible behaviour is shown by university graduates, respondents with a higher living standard, Prague citizens, and women more often than men. This corresponds to the results of the selective surveys focused on the purchasing of organic food done by Ščasný, Urban and Zvěřinová (2013), according to which women and secondary-school and university graduates purchase organic food the most often.

Other authors relativise the importance of demographic factors and emphasise psychographic factors instead. Luchs and Mooradian (2012) assume that responsible consumer behaviour is most affected by the consumer's personality. Consumers who are less conflict-seeking and more open to new experiences put a greater emphasis on environmental and social aspects of consumption as well. Since women are more likely to possess these qualities, according to the authors, they are also more likely to act as more responsible consumers. According to Fraj and Martinez (2006), consumers of environmentally friendly products are characterised by an interest in their own personal growth. In their view, such consumers will more often take action that presents a personal challenge to them.

Certain common elements occur among the reasons stated by consumers to explain why they buy or do not buy friendlier products. Based on a meta-study, Hugner (2007) summarises fifteen main types of justification for or against buying organic food. In this opinion, the main reasons include the belief that organic food is healthier and tastes better, as well as concerns for the environment, food safety, animal living conditions, and support for local economies. The reasons against included high prices, low availability, distrust of the certification system, inadequate marketing, satisfaction with existing dietary habits, and cosmetic defects attributed to organic food. According to Harper and Makatouni (2002), consumers' interest in the ethical dimension of diet plays a leading role. Consumers who do not buy organic products showed frequent distrust in the certification system, which they used to explain their disinterest in these types of foodstuffs. 
Research into the psychographic factors influencing sustainable consumer behaviour can be based on several theoretical models. Foxall, Oliveira-Castro, James, Yani-deSoriano, and Sigurdsson (2006) propose assessing the reasons for deciding whether to buy eco-friendly products or not using a behavioural perspective model (BPM), under which consumer behaviour is the result of an interplay between consumer conditions and history ${ }^{1}$. Consumer conditions represent the context of the purchase, such as the supply of alternative products, shopping conditions, and other shoppers' behaviour. Consumer history is formed by the consumer's experience. Based on both these factors, the consumer weighs the benefits (rewards) and losses (penalties) that buying the product will bring for them. These may be of a utilitarian (use of the product as such) and informational nature (the symbolic effect of the product, such as increased status). According to the authors, each purchase brings a combination of empowering and weakening, utilitarian and informational consequences. Influencing consumer behaviour, the authors say, then requires the provision of an appropriate combination of rewards for a specific type of consumer behaviour. For example, if buying a certain product is motivated by the effort to achieve a certain deed, it may be appropriate to offer such an environmentally friendlier alternative that will offer a comparable service and support it with feedback that reinforces its symbolic effect.

Other models put more emphasis on values, attitudes and beliefs in the possibilities of actively influencing the environment. In Hungerford and Volk's (1990) responsible environmental behaviour (REB) model, so-called empowerment variables play an important role, including the locus of control, and expressing an individual's belief in their ability to influence events with their behaviour. Straughan and Roberts (1999) arrived at similar conclusions. In their opinion, key factors for making decisions regarding sustainable consumption are altruistic values and perceived consumer effectiveness, i.e. the consumers' belief that they can influence environmental issues with their consumer behaviour. A secondary factor is political alignment, with liberal, left-to-centre oriented respondents showing more interest in sustainable consumption. Firat (2009) arrives at the same conclusion ${ }^{2}$. At the same time, both the studies share certain methodological limitations, i.e. data collection among university students only. One may suppose that the inclusion of more varied groups of respondents would yield other results. That said, not even a clear demographically defined group needs to be totally homogenous. Szerényi et al. (2011), for example, recognised five different patterns of attitudes to sustainable consumption in a group of Hungarian university students. Differences were also shown across study specialisations (students of natural sciences were most often represented among so-called activists, i.e. students with very modest personal consumption and a keen interest in the environment), while older students showed more interest in environmental issues than younger ones.

An emphasis on altruistic values, such as appeared in the study by Straughan and Roberts (1999), is typical for Stern's (1999) value-belief-norm (VBN) model. ${ }^{3}$ However,

\footnotetext{
${ }^{1}$ Here, the authors use the model as a certain conceptual framework and do not test it. For the principles and verification of the constituent relationships inside the model, see Foxall and Greenley (2000).

2 The study quoted makes use of the ecologically conscious consumer behaviour scale, designed by Roberts and Bacon (1997) to verify consumer behaviour. The tool monitors preference for products made of recycled paper, reduced car use, preference for biodegradable products, and consideration of energy consumption in electrical appliances.

${ }^{3}$ Stern (2000) later shifts his original model and develops it into a so-called attitude-behaviourcontext $(A B C)$ theory, including context. He says that the link between one's attitudes and behaviour
} 
the role of values in responsible behaviour is not entirely clear and open to discussion. As stated by Aertsens et al. (2009), purchasing of organic food may be related to such differing values as universalism (e.g. concern for nature) and benevolence (compassion for animals) on the one hand, and safety (healthy food) and hedonism (good food) on the other.

Follows and Jobber (2000) assume that respondents' values are influenced by their attitudes, and those in turn motivate consumers in regard to environmentally friendly shopping. In their view, the consumer assesses the individual (e.g. time investment) and environmental impacts of their consumption. The authors say that environmental attitudes are negatively correlated with conservative thinking (the tendency to stick to existing social norms). They say that egoistic values are positively correlated with an emphasis on the individual consequences of consumption. Therefore, they recommend communicating the purchase of environmentally friendly products as a simple process (reducing individual consequences) and a socially valued activity (reinforcing environmental consequences). According to Hadler and Wohlkönig (2012), values play a greater role in behaviours such as political action or protest, which are easy to "see" and thus reinforced by others, whereas they are not of such influence in individual consumer behaviour. Kaiser et al. (2005) regard as a more accurate Ajzen's $(1985,1991)$ theory of planned behaviour (TPB) model, which emphasises the importance of attitudes, social norms and beliefs in one's ability to handle certain behaviours. Urban, Zvěřinová and Ščasný (2012) document the relevance of the TPB for analysing the motivation of Czech consumers to buy organic products. In their view, the decisive factor is the respondents' attitude and subjective norms, i.e. how they think people who matter to them act.

The last perspective focuses on so-called "barriers" to sustainable consumption. They are often of a structural nature, i.e. they are understood as the result of political and economic factors. Prinet (2011), for example, considers the main barriers to be system inertia, fragmentation of initiatives promoting change, market distortion, absent political role models, issue complexity, and various lobby group influences. The Institute for Environmental Policy has examined barriers to sustainable consumption in the Czech Republic. According to the study, the main problems are insufficient education, a low level of information and weak promotion. Public administration fails to present positive examples and adequately reflect environmental criteria in allocating public contracts. Consumers' decisions are then most driven by product price and brand (Kupčíková, 2005).

On the whole, the discussion of factors motivating to sustainable consumption has, in sum, brought numerous valuable insights but also unclear conclusions. The reasons may be the breadth of the range of sustainable consumption leading to unclarity in the definition of the research object, differing demands on consumers' competencies, different roles of cultural, situational and other contextual factors, and last but not least, the diversity of the consumer category itself. This last topic is the subject of the research project presented below, developed in conjunction with BEZK, Agentura Koniklec, and Masaryk University of Brno in 2013.

is the strongest where contextual factors are neutral, and decreases to zero where the significance of the context for or against a certain behaviour becomes stronger. 


\section{Methodology}

The objective of the present study was to answer the following question:

In what ways do selected consumers legitimise their decision to buy or not to buy socially and environmentally friendlier products?

Since the objective of the study was not to establish a new model of sustainable consumer behaviour, but rather to identify and analyse motives that appeared in the respondents' justifications, we chose a qualitative research design. Within that, we organised six focus groups with a relatively homogenous population sample selected via a predefined criterion. The deliberate selection of the sample and the homogenous composition of the groups can be regarded as appropriate strategies for this type of research (Morgan, 1997; Patton, 2002). It must be noted that the study did not endeavour to maintain representativeness, and its results therefore cannot be generalised for the entire population. The selection of respondents for the groups and the venues for them were largely influenced by the limited research budget. The composition and description of the focus groups are shown in Table 1.

Whereas the first five groups were chosen in order to obtain responses from various segments of the population, the "Environmental consultants" group was chosen in order to provide possible interpretation frameworks for analysing the data obtained from the other groups.

The focus group discussions took approximately sixty minutes each. Each interview was undertaken by one interviewer, with possible additional questions by another. The conversations were recorded and the recordings were then transcribed word for word. The data were then analysed using an open coding method (Glaser and Strauss, 1967; Corbin, 2006), with individual data segments chosen from the transcripts and then coded using the open coding method. Substantive categories were added to the original codes in the second stage. These were then used for comparison among the groups.

It transpired that a relatively high degree of agreement was found among the groups in spite of the disparate demographic characteristics. The category that was seen, directly or indirectly, in almost every group was the issue of "trust", which was later renamed to "legitimisation by distrust". In the next analysis, a new category was established, "personal consumer history", to help to integrate the other categories and thus become the central category.

Below, the respondents are identified with first names and the information that they offered about themselves for research purposes. The respondents' first names have been altered to respect their anonymity.

\section{Presentation of results}

A common feature that occurred in all the respondent groups was a certain inconsistency in consumer behaviour. As a rule, the respondents bought a certain segment of products that can be called friendlier at least sometimes, while ignoring others. We refer to this selective approach as "selectively sustainable consumer behaviour".

Selectively sustainable consumer behaviour is not in conflict with the definition of sustainable consumer behaviour by Luchs and Mooradian (2012). For example, the respondents in the Officials group sometimes consciously prefer recycled paper; 
respondent mothers buy cloth nappies or organic foodstuffs; pensioners prefer local products. However, the market segment in which the consumers apply their sustainable consumption principles is selective, and respondents who buy organic foodstuffs, for example, do not prefer environmentally friendlier products in other areas, such as travel and household appliances. 
Table 1: Composition of focus groups

\begin{tabular}{|c|c|c|c|}
\hline Type of group & $\begin{array}{l}\text { Characteristics of } \\
\text { respondents }\end{array}$ & Selection criteria & Topics discussed \\
\hline Mothers & $\begin{array}{l}\text { Mothers on maternity leave. } \\
\text { Six women aged 29-35, with } \\
1-2 \text { children, five married, five } \\
\text { university graduates. }\end{array}$ & $\begin{array}{l}\text { Inhabitants of a small village on the } \\
\text { periphery of Prague. An effort was made } \\
\text { to choose respondents without explicit } \\
\text { interest in environmental issues. }\end{array}$ & $\begin{array}{l}\text { Cosmetics, } \\
\text { foodstuffs, } \\
\text { housing }\end{array}$ \\
\hline Pensioners & $\begin{array}{l}\text { Eight respondents aged 60- } \\
82 \text {, two men, six women, all } \\
\text { retired, four married, one } \\
\text { university graduate, three } \\
\text { secondary-school, two trained } \\
\text { workers, rest primary-school } \\
\text { educated. }\end{array}$ & $\begin{array}{l}\text { Inhabitants of a small village on the } \\
\text { periphery of Prague. }\end{array}$ & $\begin{array}{l}\text { Foodstuffs, } \\
\text { transport }\end{array}$ \\
\hline Students & $\begin{array}{l}\text { Six university students aged } \\
22-24 \text {, three men, three } \\
\text { women, all single. }\end{array}$ & $\begin{array}{l}\text { Students of a faculty focusing on } \\
\text { educating teachers in a big city. }\end{array}$ & $\begin{array}{l}\text { Foodstuffs, } \\
\text { travelling, } \\
\text { cosmetics }\end{array}$ \\
\hline Entrepreneurs & $\begin{array}{l}\text { Six respondents aged 33-57, } \\
\text { one man, five women, all } \\
\text { operating managers or } \\
\text { owners of shops, } \\
\text { guesthouses and restaurants, } \\
\text { all married. }\end{array}$ & $\begin{array}{l}\text { Owners and managers of tourist facilities } \\
\text { in a smaller village in a tourist area, all in } \\
\text { charge of their facilities. Effort to have } \\
\text { various types of businesses represented. }\end{array}$ & $\begin{array}{l}\text { Detergents, } \\
\text { foodstuffs, } \\
\text { energies }\end{array}$ \\
\hline Officials & $\begin{array}{l}\text { Six respondents aged } 40-55 \text {, } \\
\text { five men, one woman, five } \\
\text { married, three secondary- } \\
\text { school, the rest university- } \\
\text { educated. }\end{array}$ & $\begin{array}{l}\text { Representatives (secretaries, a mayor) } \\
\text { of municipalities with populations of } 200 \\
\text { to } 13,000, \text { in charge of procurement for } \\
\text { their institutions; as well as an financial } \\
\text { manager of a large self-governing } \\
\text { authority and a procurement manager of } \\
\text { a state organisation with approx. } 200 \\
\text { employees. }\end{array}$ & $\begin{array}{l}\text { Office supplies, } \\
\text { detergents, } \\
\text { electrical } \\
\text { appliances }\end{array}$ \\
\hline $\begin{array}{l}\text { Environmental } \\
\text { consultants }\end{array}$ & $\begin{array}{l}\text { Seven respondents aged 29- } \\
61 \text {, one woman, six men, } \\
\text { three secondary-school, the } \\
\text { rest university-educated, } \\
\text { three married, the rest single. }\end{array}$ & $\begin{array}{l}\text { Employees of citizens' associations } \\
\text { offering environmental consultancy in a } \\
\text { big city, who consult directly on } \\
\text { sustainable consumption. }\end{array}$ & $\begin{array}{l}\text { Reasons for or } \\
\text { against } \\
\text { sustainable } \\
\text { consumption, } \\
\text { structural barriers }\end{array}$ \\
\hline
\end{tabular}

As anticipated by Foxall et al. (2006), the decision to reflect environmental and social principles within a certain segment of consumer behaviour is the result of a balance of contrary motives interpreted in the respondents' personal consumer histories. In this study, we label these motives "yes forces" and "no forces". In an ongoing conflict, "yes 
forces" are weakened by reducing the credit of the sustainable consumption concept. As a result of this, selectively sustainable consumer behaviour becomes a legitimate solution.

The assumed benefits arising from sustainable consumption are chiefly integrity in relation to one's environmental awareness and accepted social norms, and expected personal benefits from environmentally friendly products. Although respondents in the Consultants group regarded the unsustainable values of the majority of society as one of the chief barriers to sustainable consumption, none of the respondents from the other groups questioned the seriousness of environmental problems (environmental awareness) or the importance of responsible environmental behaviour at the general level (social norms) during the focus groups. Some (notably mothers and students) explicitly expressed favourable environmental attitudes as the reason for their sustainable consumer behaviour:

"... we used cloth nappies too. Now we only put nappies on the child for the night, so it's no longer worth it [using cloth nappies], and therefore he gets paper diapers, but ecofriendly ones. We told ourselves clearly that we want to give preference to an environmentally friendly approach, which means... the washing of the nappies didn't weigh me down that much, but I've developed this aversion to tonnes of waste. In fact it sickens me more than the washing" (Dana, age 32, language teacher, university-educated, married, one child).

Moreover, some respondents stated a personal (or institutional) benefit that environmentally friendly consumer behaviour has for them. For respondents in the Mothers group, this was mostly a positive effect on health, be it their own or their children's. For respondents in the Students group, hitch-hiking was more enjoyable than taking the bus. For respondents in the Officials group, the organisation's image was the beneficiary. Blanka, for example, said that her municipal authority uses recycled paper for printing promotional materials:

"So that it's seen that it's eco-friendly, so that it's marked as such. So every year, when some money's left over, we purchase promotional items so that it's clearly visible on them, like fun crayons and notepads."

(Blanka, age 52, official, municipality with a population of 2200, authority employs 24, secondary-school, married)

On the other hand, sustainable consumption brings losses as well as benefits (Foxall et al., 2006). As a rule, respondents described eco-friendly products as more expensive, less functional, and more time-consuming to buy.

In the Officials group, for instance, there was recurring bad experience with recycled paper, the use of which led to increased wear on printers:

"I have experience with recycled paper. Once, on the orders from our superior in the former ministry, we procured recycled paper for copiers, and it happened many times that the copiers had to undergo more frequent maintenance, and when we added up the costs of servicing the copiers and the fact that some parts had to be replaced in the copiers; then we basically gave up on it." (Ludvík, age 55, procurement manager, state administration institution with 200 employees, secondary-school, divorced) 
Respondents in the Entrepreneurs group also referred to bad experience, saying that eco-friendly detergents are not effective enough for ordinary operations:

"We have experience, too; we've tried it; there's a company from Vrchlabi that supplies us, we've tried an eco-friendly range that should be a little more considerate, some kind of enzymatic detergent instead of lye. We put in two tins and it had no effect whatsoever." (Eva, age 36, restaurant keeper, secondary-school, married)

Negative experience with the functionality of eco-friendly products was also referred to in the Seniors, Mothers and Students groups. The perception of eco-friendly products as more expensive and less readily available was also noted in all the groups (the latter with the exception of the Officials group).

In addition, the assumed losses are magnified by the awareness of the obstacles that respondents expect to face based on their personal consumer histories. Most often, respondents referred to obstacles of an informational, situational and structural nature.

The role of information in shaping respondents' consumer histories is not entirely clear. On the one hand, for example, respondents in the Students group stated that information on eco-friendly products is readily available. On the other hand, it turned out that they are only informed about organic food and lack any practical awareness of other eco-friendly products.

Respondents in multiple groups stated that there is too much information available, for example, too many different types of labelling on product packaging, making it hard for them to navigate. According to respondents in the Consultants group, the system of ecolabelling of products is poor and leads to confusion among the public. Respondents thus face not a lack of information but the opposite: ex-formation (Gore, 2000).

"We have, or most of us, have a problem with this information. What is and what isn't eco-friendly. As we've more or less orientated ourselves based on, as Honza put it, that the thing's riddled with labels, based on one label or another. But it's harder when you read the ingredients and there's no label, then it's hard to know whether it's eco-friendly" (Valérie, age 36, guesthouse keeper, university, married).

Respondents in the Mothers group agreed that they lack an authoritative source of information that they could trust providing balanced information on eco-friendly products.

"I'd be happy enough if there was a website (...), that I'd learn about and that it's there; if it had a comparison with conventional products, I would seek it out, and I'd especially look forward to tests of eco-friendly laundry detergents in D-Test and I'd focus on reading it thoroughly and comparing the ones that I was curious about. It might not be published in a magazine, but if there was a website like I said or a column in an existing paper, I'd find out about it, and I'd visit it regularly... If families wrote something there like we've tried these three things, I'd be happy with that. Like somebody's experience, so I could have a look to see if I even want to try that" (Adéla, age 32, bank clerk, secondaryschool, partner, 1 child).

Respondents did admit that they could theoretically find the information themselves. However, deciding on what to trust is time-consuming for them. Their source of trustworthy information is then replaced with social networks - the experience and recommendations of friends and other reference persons: 
"It depends a lot on what you come across at your friends' or the people around you. It's often crucial that somebody beats the path for you, does the big research, puts in those hours of time, does the tests, spends the time on it. And then they find the way, and only pass on the know-how. For a person who sees that, it's then tremendously easy to just start out that way. In fact, we also started to use cloth nappies after we'd seen them at our friends', who'd walked the hard path, but them we got the diapers from them" (Dana, age 32, language teacher, university-educated, married, one child).

The structural obstacles mostly concerned the complexity of the administrative settings or institutional measures that disadvantage or restrict environmentally friendly behaviour. For example, a respondent in the Entrepreneurs group gave the reasons why he had not made use of the Green Light to Savings scheme for his company as the reluctance of administrative staff in charge. Respondents in the Consultants group stated how project requirement settings had prevented them from procuring more eco-friendly products. Several respondents in the Officials group agreed that it is virtually impossible to procure recycled paper for their authorities due to the rules set for tenders:

"Well, everybody keeps saying today that you can use any requirements you like, you have to proceed in a non-discriminatory and transparent fashion, which is fundamental requirement no. 1 , but woe betide anyone should you do something different and under another criterion than price. Any one of those rejected will appeal against your decision; you have to justify it, and honestly you don't have the team to justify what a gang of lawyers from an established law firm handling millions of crowns say. They shoot you down in flames, so tenders today are made exclusively according to the price." (Mirek, age 44, municipal authority secretary, population: 2500, university, married)

Respondents thus documented the paradoxical behaviour of their superiors: promotional materials, published in relatively few copies, are made on "eco-friendly" paper, while the "invisible" ordinary operation with much larger consumption uses cheaper non-recycled paper. According to respondents in the Entrepreneurs group, organic food is not available in their region, plus consumers are not interested in it. Buying it would lead to restaurant meals becoming more expensive, which would discourage their clientele:

"They don't ask for it straight out. They'd definitely be happy if it was offered, but they won't come to ask us straight away, 'Is it made with organic ingredients?' That's never happened. But the truth is what Honza here says, they won't pay for it." (Aneta, age 35 , owner of a guesthouse for school camps, skiing courses and families with children, secondary-school, married)

The expected benefits, losses and obstacles together make up a consumer's personal consumption history. Based on this, respondents then decide whether to buy any eco-friendly products and which to buy. The weighing up of the "yes forces" and the "no forces" is further reinforced or weakened with new experience of eco-friendly products. Consumer habits also play an important role; they may both reinforce and preclude sustainable behaviour. Respondents in the Mothers, Students and Seniors groups stated that their decisions are often based on established habits, routines that they get into and then do not rethink. The seniors in the sample direct their consumption behaviour mainly according to price and good experience. Another important criterion for them is the origin of the product: they prefer Czech products and, in particular, those that come from somebody that they know in person and are used to buying from.

The balance of the "yes forces" and the "no forces" in respondents' personal consumer histories is further deflected by questioning the credibility of sustainable 
consumption. This motive occurred in all the groups except the Consultants. Respondents in the Mothers group lacked trustworthy information that would enable them to convincingly distinguish between eco-friendly and conventional products. The opinion among the Students group was that information on organic food is not balanced and is of either a negative or a promotional nature. The Officials group questioned the credibility of the State's effort regarding sustainable consumption as it was in conflict with actual policy. They also questioned the credibility of the state-guaranteed labelling of organic food:

"But then we face the fact that the information that we get is not always of adequate quality. Because we know examples from other industries; take environmentally friendly solar power plants, which are going to be an environmental problem in a few years, not long from now. So, after such excesses, a lot of people are simply sceptical about a thing being a truly eco-friendly product. Which reminds me, do you know the difference between a conventional foodstuff and an organic one? Organic food is only fertilised at night." (Mirek, age 44, municipal authority secretary, population: 2500, university, married)

Fundamental distrust occurred in the Seniors group, too, who questioned not only the environmental friendliness of the foodstuffs, but the functioning of the overall national system of environmental protection:

"We heated the house with a boiler, we burnt everything in it, sure it went up into the air, but then again we didn't have a full rubbish bin, which is taken away somewhere and burnt all the same, telling us their burning is clean, but we don't really believe that. We had ashes in our bin..." (Karla, age 60, schoolmistress, secondary-school, divorced)

\section{Discussion}

In spite of its slow growth (Hadler and Wohlkönig, 2012), sustainable consumption remains a marginal phenomenon in the Czech Republic. Although the results of the present research cannot be generalised, it seems that the cause is not the low environmental awareness of the public, i.e. that respondents would not know about environmental problems and that their consumer behaviour affects the state of the environment. Environmental protection has become a social norm that respondents do not question. They also repeatedly gave examples of having tried to buy more environmentally friendly products, whether they be recycled paper, eco-friendly detergents or cosmetics. However, their efforts to align the accepted social norm with their own consumer behaviour is undermined by practical obstacles, bad experience and distrust.

The respondents assume that the price for respecting the social norm is a product that is more expensive, less functional and more demanding of time and energy to acquire. If they see role models around thems (such as the Mothers group respondents), they like to follow them. More often, however, they have the feeling that sustainable consumption is not promoted very much and they do not see such role models.

Distrust as an argument against sustainable consumption has appeared in other studies; for example in the Czech Republic in Ščasný et al. (2013). Some qualitative studies mention it abroad (Harper and Makatouni, 2002; Lockie et al., 2002). It can therefore be assumed that this motive plays an important role in Czech consumers' decision-making and is not culture-specific for the Czech Republic.

At the same time, it is not clear from the research undertaken whether distrust expresses the environmentally conscious respondents' authentic belief concerning untrustworthy labelling of eco-friendly products or whether some use it as an "excuse" to 
defend insufficient internal motivation to buy such products. An alternative explanation would then assume that the social norm ("sustainable consumption is right") is not in line with the respondent's personal norms. The significance that respondents (especially mothers and seniors) attributed to the opinions and behaviour of their social surroundings indicates that in addition to "big" norms derived from society-wide discourse ("sustainable consumption is right"), people place emphasis on the the "small" norms of their respective communities: friends, neighbours or family. If these "big" and "small" norms are in contradiction, a partial questioning of the requirements arising from one of them and finding a compromise in the form of selectively sustainable consumption may be an acceptable solution.

The effort of various entities to improve consumers' information has ironically led to an oversaturation with ex-formation (Gore, 2000), with consumers not knowing what to trust and what the different information and labels in fact mean. They lack an intelligible and trustworthy source that would help them discern which products are eco-friendly and which are not.

Consumers then resolve the conflict between the "yes forces" and the "no forces" with a certain compromise, where they seek out eco-friendly products in the market segment that is the most easily available to them and offers them the most benefits regardless of its actual environmental benefit. This "selectively sustainable consumer behaviour" is further legitimised by reducing the credibility of the sustainable consumption concept, which occurred in all the focus groups. Thus, in exchange for the "symbolic" act of selectively sustainable consumer behaviour, respondents acquire integrity with their own environmental consciousness and the accepted social norm irrespective of their own environmental footprint (Jurin and Fortner, 2002).

The present study offers numerous implications for the implementation of consumeroriented environmental education. The first one is to establish consumer trust in the system of information about eco-friendly products (cf. Ščasný et al., 2013). An appropriate vehicle might be to set up a trustworthy information system that would provide unbiased and balanced information on the environmental and social aspects of foodstuffs and consumer goods, along with an assessment of their functionality and price compared to similar conventional products.

The emphasis on social networks as a source of trustworthy information supports the organisation of community-based rather than blanket information campaigns (McKenzie-Mohr, Schultz, Lee, and Kotler, 2012). Vermier and Verbeke (2006) state that although sustainable consumption may be related to consumers' value orientation, campaigns appealing to "common good" and "ethical consumption" are not the way that would change consumer behaviour within a short time. Rather, they believe the solution is to explain the significance of sustainable consumption for the consumer as such, inform them about availability (e.g. by providing Internet addresses from which organic food can be ordered in the region), and reinforce social norms in the community. Such campaigns would make it possible to include a social network of respondents and set up a certain "community of practice", the members of which would exchange experience and learn about sustainable consumption from each other (Wenger, 2000; Prinet, 2011).

Finally, one cannot ignore the fact that "selectively sustainable consumer behaviour" was represented in the research by activities that are relatively undemanding on respondents' competencies. Including individual contextual factors leads to situations where consumers require competencies for autonomous interpretation of situations rather than simple guidelines. Therefore, while the decisive factor for buying organic food may be 
the provision of the email address of a farmer operating near the consumer, reducing energy consumption in a household requires a consumer to make a series of complex decisions involving an analysis of energy losses, available sources of energy, potential savings, etc. Therefore, environmental education should develop such "action competencies" from childhood that will enable consumers to make autonomous decisions in the uncertain dynamic conditions of the future (Wals, 2012). They may be based on knowledge of possible strategies for resolving situations (action-related knowledge), as well as their effectiveness in a given situation (effectiveness knowledge) (Roczen, Kaiser, Bogner, and Wilson, 2013). However, one's own conviction of one's ability to solve such situations will probably also play an important role (Bandura, 1977, Ajzen, 1991). In an environmental education context, a possible solution might be "emancipation" oriented programmes, i.e., such programmes that emphasise participants' (pupils', adults') autonomy, participation and accountability when choosing programme objectives and activities (Wals, Geerling-Eijff, Hubeek, van der Kroon, and Vader, 2008).

The above recommendations call for types of consumer-oriented environmental education programmes that are not particularly widespread in the Czech Republic at present. Therefore, their practical implementation should include verification of their effectiveness and broader research into their influence on the consumer behaviour of target groups.

\section{Conclusion}

The objective of this study was to propose principles for developing consumeroriented environmental education programmes based on an examination of barriers to sustainable consumer behaviour. The research was based on an analysis of qualitative data obtained by means of focus groups with six different categories of respondents.

Based on the focus groups, we can assume that the main barrier is not low environmental awareness of the public, but the denial of the importance of sustainable consumption at the general level. The absence of trust in the national system of labelling eco-friendly products, structural barriers, negative experience with such products, and their lower availability were recurring arguments. Social networks - the experience and opinions of friends and reference persons - also played an important role in the respondents' decision-making.

Effective consumer-oriented environmental education programmes should therefore probably not be mere efforts to "inform" the target groups about the "problem" and its possible solution at the level of particular consumer behaviour. Instead, an effective programme should probably be tailored to the specific context of the target group (e.g. issue a list of addresses from which eco-friendly products can be bought in the region), and it should develop consumers' competencies towards critical assessment of available product information. In addition, consumers' willingness to buy more eco-friendly products would be further increased by a trustworthy information system in which the advantages and drawbacks of particular products can be discussed. The programmes should also take into account the participants' social background and the norms established by each community. Therefore, the solution might be programmes tailored to specific communities - based on their needs and capabilities, discussing their doubts, and using language that is intelligible to them. The programme should promote the sharing of positive experience with selected products among the community members, as well as open discussion of any negative experience. 
Last but not least, public administration authorities should maintain consistency with promoting sustainable consumption in their everyday operations as well, and not create structural barriers that question the sustainable consumption concept in the public's eyes.

The present research project is a partial exploration of the motives related to sustainable consumer behaviour. In order to verify its results, further surveys are recommended that might focus in more depth on some of the groups of respondents examined here, or provide additional, quantitative data on consumer attitudes and the behaviour of selected target groups.

\section{References}

- Aertsens, J., Verbeke, W., Mondelaers, K., \& Huylenbroeck, G. V. (2009). Personal determinants of organic food consumption: a review. British Food Journal, 111(10), 1140-1167. Retrieved from http://www.emeraldinsight.com/10.1108/00070700910992961 http://dx.doi.org/10.1108/00070700910992961

- Ajzen, I. (1985) From Intentions to Actions: A Theory of Planned Behavior. In Kuhl J, \& J. Beckman (Eds.), Action Control. From Cognition to Behavior. Berlin: Springer.

- Ajzen, I. (1991). The Theory of Planned Behavior. Organizational Behavior and Human Decision Process , 50(2), 179-211. Retrieved from http://linkinghub.elsevier.com/retrieve/pii/074959789190020T http://dx.doi.org/10.1016/0749-5978(91)90020-T

- Angelovska, J., Sotiroska, S. B., \& Angelovska, N. (2012). The impact of environmental concern and awareness on consumer behaviour. Journal of International Environmental Application and Science, 7(2), 406-416.

- Anon, (2005). Co je doma, to se počítá. Praha: Český ekologický ústav.

- Bandura, A. (1977). Self-efficacy: Toward a unifying theory of behavioral change. Psychological Review, 84(2), 191-215. Retrieved from http://content.apa.org/journals/rev/84/2/191 pmid:847061 http://dx.doi.org/10.1037/0033-295X.84.2.191

- Činčera, J. (2013). Evaluation of an educational exhibition on global issues and consumer responsibility: From involvement to hopelessness. Envigogika, 8(2), 10. Retrieved from http://www.envigogika.cuni.cz/index.php/Envigogika/article/view/376 http://dx.doi.org/10.14712/18023061.376

- Chan, R. Y. K. (1999). Environmental attitudes and behavior of consumers in china: Survey findings and implications. Journal of International Consumer Marketing, 11(4), 25-52. Retrieved from http://www.tandfonline.com/doi/abs/10.1300/J046v11n04_03 http://dx.doi.org/10.1300/J046v11n04_03 
- Charmaz, K. (2006). Constructing Grounded Theory. Practical Guide Through Qualitative Analysis. London; SAGE, 2006: Thousand Oaks: Sage.

- C Cvvm, (2013). Vztah k životnímu prostredí a chování domácností - květen 2013. Praha: Centrum pro výzkum veřejného mínění. Sociologický ústav AV ČR.

- Firat, D. (2009). Demographic and psychographic factors that affect environmentally conscious consumer behavior: A study at Kocaeli university in Turkey. Journal of American Academy of Business, 14(2), 323-329.

- Follows, S. B., \& Jobber, D. (2000). Environmentally responsible purchase behaviour: a test of a consumer model. European Journal of Marketing, 34(5/6), 723-746. Retrieved from http://www.emeraldinsight.com/10.1108/03090560010322009 http://dx.doi.org/10.1108/03090560010322009

- Foxall, G. R., \& Greenley, G. E. (2000). Predicting and Explaining Responses to Consumer Environments: An Empirical Test and Theoretical Extension of the Behavioural Perspective Model. The Service Industries Journal, 20(2), 39-63. Retrieved from http://www.tandfonline.com/doi/abs/10.1080/02642060000000019 http://dx.doi.org/10.1080/02642060000000019

- Foxall, G. R., Oliveira-Castro, J., James, V. K., Yani-de-Soriano, M. M., \& Sigurdsson, V. (2006). Consumer behavior analysis and social marketing: the case o environmental conservation. Behavior and Social Issues, 15(1), 101-112. Retrieved from http://journals.uic.edu/ojs/index.php/bsi/article/view/338 http://dx.doi.org/10.5210/bsi.v15i1.338

- Fraj, E., \& Martinez, E. (2006). Environmental values and lifestyles as determining factors of ecological consumer behaviour: an empirical analysis. Journal of Consumer Marketing, 23(3), 133-144. Retrieved from http://www.emeraldinsight.com/10.1108/07363760610663295 http://dx.doi.org/10.1108/07363760610663295

- Glaser, B. G., \& Strauss, A. (1967). The Discovery of Grounded Theory: Strategies for qualitative research. New Brunswick, London: Aldine Translaction.

- Gore, A. (2000). Země na misce vah. Ekologie a lidský duch. Praha: Argo.

- Hadler, M., \& Wohlkönig, P. (2012). Environmental behaviours in the Czech Republic, Austria and Germany between 1993-2010: Macro-level trends and individual-level determinants compared. Sociologický časopis, 48(3), 467-492.

- Harper, G. C., \& Makatouni, A. (2002). Consumer perception of organic food production and farm animal welfare. British Food Journal, 104(3/4/5), 287-299. Retrieved from http://www.emeraldinsight.com/10.1108/00070700210425723 http://dx.doi.org/10.1108/00070700210425723

- Hugner, R. S., McDonagh, P., Prothero, A., Schulty, C. J., \& Stanton, J. (2007). Who are organic food consumers? A compilation and review of why people purchase organic food. Journal of Consumer Behavior, 6, 1-17. 
- Hungerford, H. R., \& Volk, T. L. (1990). Changing Learner Behavior Through Environmental Education. The Journal of Environmental Education, 21(3), 8-21. Retrieved from http://www.tandfonline.com/doi/abs/10.1080/00958964.1990.10753743 http://dx.doi.org/10.1080/00958964.1990.10753743

- Jurin, R. R., \& Fortner, R. W. (2002). Symbolic Beliefs as Barriers to Responsible Environmental Behavior. Environmental Education Research, 8(4), 373-394. Retrieved from http://www.tandfonline.com/doi/abs/10.1080/1350462022000026791 http://dx.doi.org/10.1080/1350462022000026791

- Kaiser, F. G., Hubner, G., \& Bogner, F. X. (2005). Contrasting the Theory of Planned Behavior With the Value-Belief-Norm Model in Explaining Conservation Behavior. Journal of Applied Social Psychology, 35(10), 2150-2170. Retrieved from http://doi.wiley.com/10.1111/j.1559-1816.2005.tb02213.x http://dx.doi.org/10.1111/j.1559-1816.2005.tb02213.x

- Kupčíková, L. (2005). Hrozby a príležitosti udržitelné spotřeby v ČR. Environmentální značení, 7(1-2), Retrieved from http://www.mzp.cz/ris/ekodisknew.nsf/6d13b004071d0140c12569e700154acb/003d1ef6fe22f885c12573fa00 6b12b4/\$FILE/Enviznaceni\%201a2_2005.pdf

- Laroche, M., Tomiuk, M., Bergeron, J., \& Barbaro-Forleo, G. (2009). Cultural Differences in Environmental Knowledge, Attitudes, and Behaviours of Canadian Consumers. Canadian Journal of Administrative Sciences / Revue Canadienne des Sciences de l'Administration, 19(3), 267-282. Retrieved from http://doi.wiley.com/10.1111/j.1936-4490.2002.tb00272.x http://dx.doi.org/10.1111/j.1936-4490.2002.tb00272.x

- Laštůvka, P., Kellnerová, D., \& Křivánková, D. (2008). Jak na ekologické zemědělství. Brno: Rezekvítek.

- Lea, E., \& Worlsey, A. (2005). Australians' organic food beliefs, demographics and values. British food journal, 107(11), 855-869.

- Lockie, S., Lyons, K., Lawrence, G., \& Mummery, K. (2002). Eating "Green": Motivations behind organic food consumption in. Australia. Sociologia Ruralis, 42(1), 23-40. Retrieved from http://doi.wiley.com/10.1111/1467-9523.00200 http://dx.doi.org/10.1111/1467-9523.00200

- Luchs, M. G., \& Mooradian, T. A. (2012). Sex, Personality, and Sustainable Consumer Behaviour: Elucidating the Gender Effect. Journal of Consumer Policy, 35(1), 127-144. Retrieved from http://link.springer.com/10.1007/s10603-0119179-0 http://dx.doi.org/10.1007/s10603-011-9179-0

- Maliřová, E. et al., (2008). Hořká chut' čokolády. Kakao a dětská práce. Brno: Společnost pro Fair Trade. 
- Malírová, E. (2008). Komu chutná prales. Náš vztah k pralesu a jeho kácení. Brno: Společnost pro Fair Trade.

- Malírová, E. et al., (2011). PodObal. Př́ručka pro výuku o globálních souvislostech našeho obchodování. Brno: NaZemi.

- Martín, E. A., Ródenas, M. J. L., Serrano, P. G., \& Fernández, N. G.. Spotřebitelské vzdělávání ve třídách. Základní príručka. Praha: E-CONS.

- Marcinkowski, T. (2005) Predictors of Responsible Environemental Behavior. A Review of Three Disertation Studies. In Hungerford, H.R., Bluhm, W. J., Volk, T.L. and Ramsey, J. M (Ed.), Essential Readings in Environmental Education (pp. 265294). Champaign: Stipes.

- McKenzie-Mohr, D., Schultz, P. W., Lee, N. R., \& Kotler, P. (2012). Social Marketing to Protect the Environment: What Works. Thousand Oaks, CA: Sage.

- Morgan, D. L. (1997). Focus groups as qualitative research. Newbury Park, Calif: Thousand Oaks: Sage.

- NaZemi. Supermarket SVĚT. Interaktivní výstava [internal material]. Brno: NaZemi.

- Noor, N. A. M., Muhammad, A., Kassim, A., Jamil, C. Z. M., Mat, N., Mat, N., \& Salleh, H. S. (2012). Creating green consumers: how environmental knowledge and environmental attitude lead to green purchase behaviour?. International Journal of Arts and Sciences, 5(1), 55-71.

- Patton, M. Q. (2002). Qualitative research and evaluation methods. Thousand Oaks, Calif: Sage Publications.

- Prinet, E. (2011). Sustainable consumption and production. Vancouver: One Earth. Retrieved from http://scpgreenbuild.files.wordpress.com/2011/01/background_paper_1_sust_c ons_prod.pdf

- Roberts, J. A., \& Bacon, D. R. (1997). Exploring the Subtle Relationships between Environmental Concern and Ecologically Conscious Consumer Behavior. Journal of Business Research, 40(1), 79-89. Retrieved from http://linkinghub.elsevier.com/retrieve/pii/S0148296396002809 http://dx.doi.org/10.1016/S0148-2963(96)00280-9

- Roczen, N., Kaiser, F. G., Bogner, F. X., \& Wilson, M. (2013). A competence model for environmental education. Environment and Behavior, 20(10), 1-21.

- Rykovská, A. (2006). Žijeme spolu aneb jak na téma ochrany zvírat. Praktická príručka pro pedagogy 2. stupně základních škol a pedagogy středních škol. Praha: SSEV Pavučina.

- Soyez, K. (2012). How national cultural values affect pro-environmental consumer behavior. International Marketing Review, 29(6), 623-646. Retrieved from http://www.emeraldinsight.com/10.1108/02651331211277973 http://dx.doi.org/10.1108/02651331211277973 
- Stern, P. C., Dietz, T., Troy, A., Guagnano, G. A., \& Kalof, L. (1999). A ValueBelief-Norm Theory of Support for Social Movements: The Case of Environmentalism. Human Ecology Review, 6(6), 81-97.

- Stern, P. C. (2000). New Environmental Theories: Toward a Coherent Theory of Environmentally Significant Behavior. J Social Isssues, 56(3), 407-424. Retrieved from http://doi.wiley.com/10.1111/0022-4537.00175 http://dx.doi.org/10.1111/0022-4537.00175

- Straughan, R. D., \& Roberts, J. A. (1999). Environmental segmentation alternatives: a look at green consumer behavior in the new millennium. Journal of Consumer Marketing, 16(6), 558-575. Retrieved from http://www.emeraldinsight.com/10.1108/07363769910297506 http://dx.doi.org/10.1108/07363769910297506

- Szerényi, Z. M., Ágnes, Z., \& Anna, S. (2011). Consumer behaviour and lifestyle patterns of Hungarian students with regard to environmental awareness. Society and Economy, 33(1), 89-109. Retrieved from http://www.akademiai.com/openurl.asp?genre=article\&id=doi:10.1556/SocEc. 33.2011.1.8 http://dx.doi.org/10.1556/SocEc.33.2011.1.8

- Šimonová, P., Činčera, J., Jančaříková, K., \& Volfová, A. (2013). Ekologická a environmentální výchova. Plzeň: FRAUS.

- UNEP (2013). About the Marrakech Process. Towards a global framework for action on sustainable consumption and production. UNEP. Retrieved from http://www.unep.fr/scp/marrakech/about.htm

- Urban, J., Zvěřinová, I., \& Ščasný, M. (2012). What motivates Czech consumers to buy organic food? Sociologický časopis, 48(3), 509-536.

- Ščasný, M., Urban, J., \& Zvěřinová, I. (2013). Environmentally significant behaviour in the Czech Republic: Energy, food and transportation. Praha: Karolinum.

- Vermier, I., \& Verbeke, W. (2006). Sustainable food consumption: Exploring the consumer-"attitude-behavioral intention" gap. Journal of Agricultural and Environmental Ethics, 19(2), 169-194. Retrieved from http://link.springer.com/10.1007/s10806-005-5485-3 http://dx.doi.org/10.1007/s10806-005-5485-3

- Wals, A. E. J. (2012) Learning our way out of un-sustainability: the role of environmental education. In S. Clayton (Ed.), The Oxford Handbook of Environment and Conservation (pp. 628-644). Oxford: Oxford university press.

- Wals, A. E. J., Geerling-Eijff, F., Hubeek, F., van der Kroon, S., \& Vader, J. (2008). All Mixed Up? Instrumental and Emancipatory Learning Toward a More Sustainable World: Considerations for EE Policymakers. Applied Environmental Education \& Communication, 7(3), 55-65. Retrieved from http://www.tandfonline.com/doi/abs/10.1080/15330150802473027 http://dx.doi.org/10.1080/15330150802473027 
- Wenger, E. (2000). Communities of Practice and Social Learning Systems. Organization, 7(2), 225-246. Retrieved from http://org.sagepub.com/cgi/doi/10.1177/135050840072002 http://dx.doi.org/10.1177/135050840072002

This paper was elaborated with the support of the TACR project "Evaluation of effectiveness of environmental education tools". Project no.: TB010MZP056. Any dissemination of this document is only permitted with explicit prior consent of the TACR.

\section{Jan Činčera}

Masaryk University Brno, Department of Environmental Studies \& Technical University of Liberec, Department of Pedagogy and Psychology

The author focuses on theory of environmental education and education for sustainable development. He cooperates with environmental centres as a programme consultant and evaluator.

Jan Stejskal (BEZK)

Martin Mach (BEZK)

Miroslav Lupač (Agentura Koniklec) 